\title{
Intellectualization of Human Capital Development in the Digital Economics: the Importance for Improvement of Economic Security of Enterprises
}

\author{
Olena Arefieva, Olga Polous, Volodymyr Arefiev, Yuri Kopcha
}

\begin{abstract}
The article defines the prerequisites that actualize the study of intellectualization of human capital development in the digital economy. The importance of intellectual capital in securing innovative development of society and enhancing competitive positions on a global scale while using modern information technologies are emphasized. The necessity of increasing the motivation to receive education, which meets the needs of business structures in the digital economy is determined. The importance of formation of digital competencies of key groups that are under study by the leading international organizations of the world is determined. The importance of developing new approaches to the process of realizing the potential of economic security of enterprises during the digitization of the economy is emphasized. The peculiarities of the interconnection of the process of intellectualization of human capital and economic security of enterprises in the digital economy are identified.
\end{abstract}

Keywords: digital economics, economic security, human capital, intellectualization.

\section{INTRODUCTION}

As the economy moves to a fundamentally new level, accompanied by the widespread use of digital technologies, its competitive advantages and opportunities for further modernization are largely determined by existing and realized human capital. Opportunities for economic, social and technological modernization of a particular society are determined by people: their education, qualifications and experience. In today's Ukrainian realities, human capital as a factor of innovative development in the digital economy has received little attention, which prevents enterprises from adapting to the pace of technology and technology updates in a timely manner. Efforts of the national innovation system are directed, first of all, to the development of innovative infrastructure and to the formation of effective institutions, which should become the basis for improving the efficiency of its functioning.

\section{LITERATURE REVIEW}

Intellectualization of human capital development is a complex, multilateral and multifactorial process. A number of national and foreign scientists, leading international organizations, and state structures of individual countries are engaged in studying its separate sides.

In particular, the works of T. Blyznyu, T. Lepeyko [13], A. Subetto [12], A. Kolota, O. Gerasimenko [5], R. G. Stein, G. Pinchot [11], Chun Wei Choo [1], M. Rubinstein [9], A. Firstenberg was investigated in the context of development of human capital and its intellectual component. Annual reports and surveys conducted within the International Labor Organization [4], the World Economic Forum [14], the OECD [7], the Global Competitiveness Index [2] and the Global Innovation Index [3] were also used.

The works of V. M. Mykhailenko, S.O. Arefiev [6], V.V. Prokhorova, B. I. Yatsenko [8] are dedicated to improving the economic security of an enterprise, which can be achieved by bringing the dynamics of human capital development to the requirements of the digital economy.

\section{FORMULATION OF RESEARCH OBJECTIVES}

The main purpose of this study is to assess the impact of intellectualization of human capital development in the digital economics on the improvement of economic security of enterprises. To achieve this goal have been determined following tasks: most problematic factors for doing business in Ukraine in the context of intellectualization of human capital was systematized; reasons that lead to increasing motivation to receive education that will be appropriate digital economic conditions was installed; approaches to the formation of economic security potential management mechanism of enterprises in the digital economics were proposed; the interconnection of the process of intellectualization of human capital and economic security of enterprises in the digital economy was specified.
Revised Version Manuscript Received on October 15, 2019.

Olena Arefieva, National Aviation University, Department of Air Transport Economics, Kyiv, Ukraine. (Email: lena-2009-19@ukr.net )

Olga Polous, National Aviation University, Department of Air Transport Economics, Kyiv, Ukraine. (Email: polousolgavictorovna@gmail.com)

Volodymyr Arefiev, Prima Leader Group, Kyiv, Ukraine. (Email: arefievvolodymyrolegovich@gmail.com)

Yuri Kopcha, National Aviation University, Department of Air Transport Economics, Kyiv, Ukraine. (Email: 17-19rosts@ukr.net) 


\section{PRESENTATION OF THE MAIN RESEARCH MATERIAL}

In the new century, information and intellectualization of all spheres of human life and the very carriers of these characteristics - people, are coming to the fore. At the same time, they can be a major threat to information security not only in our country but also in the world. Insufficient skills, low digital skills, and misunderstandings of the emerging processes within a transformed economy by enterprise employees may expose it to the increasingly widespread threats to the enterprise's economic security, both as a trade secret for unique competitive advantages and the movement of information. Remote work and freelancing are increasingly attracting a new generation of employees, but at the same time have hidden financial and reputational risks for businesses using the technology, as late or incorrect upgrades of operating systems on devices can lead to suspension indefinitely.

In the context of these changes, more and more businesses are becoming more aware of the need for artificial intelligence to ensure cybersecurity: data protection, identification, device protection and information while their employees are online or on corporate networks. It enables innovative businesses to operate in line with advanced digital security standards, but requires new-age staff to have a deep understanding of the processes in the digital economy, increase their own technology knowledge's, skills and individual human capital as a guarantee of economic security for the digital economy.

Thus, the innovative development of the state and individual economic entities implies not only the creation of the latest technologies, but also their effective introduction into the production process, modern technologies for the promotion of manufactured products to the market, the formation of innovative communication infrastructure. In the given conditions, in our opinion, in the priority is the intellectual capital, which is able to provide a sufficient level of innovative development of society and a worthy place in the competitiveness of the economic systems of the world.

As of 2018, our country ranks 81st in the Global Competitiveness Index ranking, which is ahead of the previous survey by 4 rating points in 2016 [2]. On Fig. 1. provides a matrix of the main components of this index for our country in 2017-2018.

Despite the increase in positions in this rating, the most problematic factors for doing business in Ukraine and, as a consequence, for enhancing its investment attractiveness for foreign investors, among all other whole four positions are relegated to factors that affects the formation and development of human capital - not enough educated workforce, poor (low) work ethic in the national workforce, lack of ability to innovate (innovation), restrictive labor standards (Figure 2).

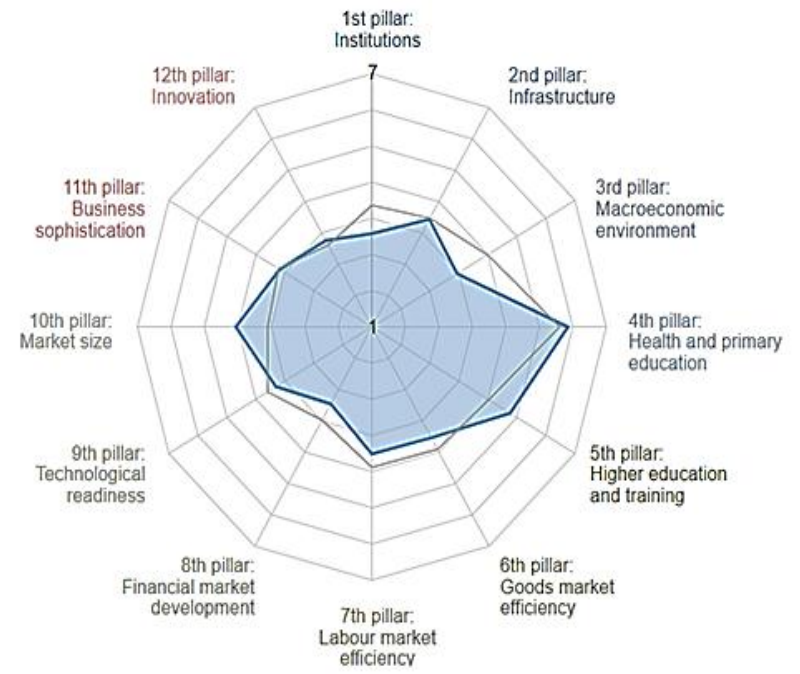

Fig. 1. Global Competitiveness Index 2017-2018 of Ukraine (81 place from 137 economies)

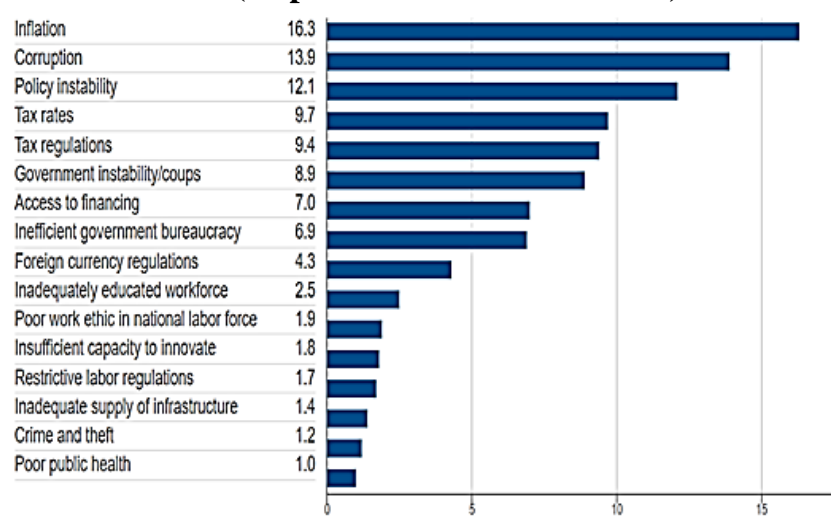

Fig. 2. Most problematic factors for doing business in Ukraine, 2017-2018

One of the main causes of "brain drain" and threats to the functioning of enterprises, of course, is the low demand for skilled labor, which is expressed in the desire of Ukrainian skilled and talented professionals to live and work abroad, as in Ukraine their work was "unnecessary" to society. However, despite such an assessment by the experts themselves, in fact, labor productivity and human capital in the Ukrainian economy are closely linked.

The last decade has been characterized by the rapid development of information and communication technologies, which have ceased to be a separate area of activity and have become a recognized trend, including economic. The development of these technologies within the individual state and its entrepreneurial structures requires increasing motivation to receive education that will be appropriate in time. According to the information provided on the official website of the State Statistics Service of Ukraine, as of the beginning of the 2018-2019 academic year, the number of Bachelor in humanitarian specialties still significantly exceeds the number of students in technical specialties and specialties related to information security (Figure 3a and Figure 3b) [10]. 

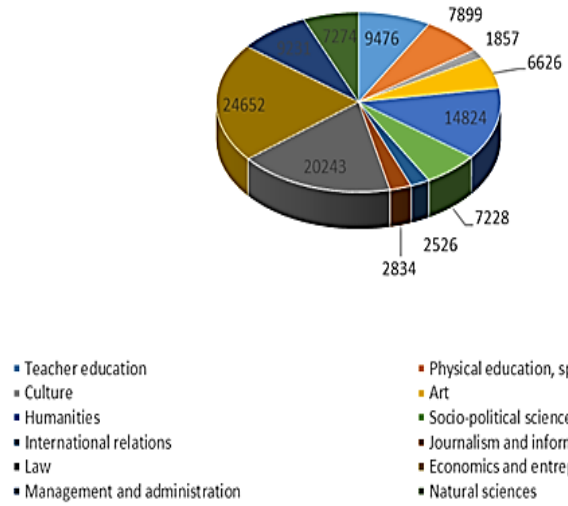

Fig. 3a. Number of students at ZWO at the beginning of the 2018/19 academic year by Bachelor's Degree in the areas of study (humanities)

In the context of the above trends, it is logical to raise the issue of logistics for innovative education in the digital economy, which costs more than, for example, the humanities.

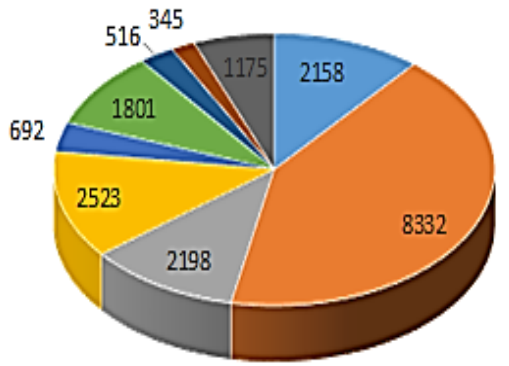

- Systems Sciences and cybernetics

- Computer science and computer engineering

- Automation and Control

- Elertrical engineering and electromechanics

- Electronics

- Radio engineering, electronic devices and communication

- Metrology, measuring equipment and information-measuring technologies

- Aviation and space rocket technology

Fig. 3b. Number of students at ZWO at the beginning of the 2018/19 academic year by Bachelor's Degree in the areas of study (technical areas)

But, of course, information and communication technologies should become an integral part of the educational infrastructure, including, actively, integration into the educational and professional programs of socio-humanitarian specialties, because they have a direct impact on the efficiency and quality of the learning process, opening new opportunities to the applicants for gaining more up-to-date, innovative knowledge. This statement emphasizes the need to develop digital competences of different nature, which are explored by a number of leading international organizations in the world (Table 1).
Table- I: The main categories of digital competence

\begin{tabular}{|c|c|}
\hline Category & Competences set \\
\hline $\begin{array}{l}\text { Willingness to apply } \\
\text { digital skills for decent } \\
\text { jobs (International } \\
\text { Labor Organization and } \\
\text { International } \\
\text { Telecommunication } \\
\text { Union (ITU)) }\end{array}$ & $\begin{array}{l}\text { Basic digital skills } \\
\text { (technology-related) } \\
\text { Communication skills (such as } \\
\text { communication and leadership) } \\
\text { Ready-to-use digital skills for } \\
\text { decent jobs (International } \\
\text { Labor Organization and } \\
\text { International } \\
\text { Telecommunication Union } \\
\text { (ITU)) } \\
\text { Digital Business (Internet) - } \\
\text { market research and use of } \\
\text { financial platforms }\end{array}$ \\
\hline $\begin{array}{lr}\text { Professional } & \text { Skills } \\
\text { (World } & \text { Economic } \\
\text { Forum) } & \end{array}$ & $\begin{array}{l}\text { Abilities (cognitive and } \\
\text { physical) } \\
\text { Basic skills (content and } \\
\text { processing skills) } \\
\text { Cross-functional skills (social } \\
\text { systems, complex problem } \\
\text { solving, resource management } \\
\text { and technical skills) }\end{array}$ \\
\hline $\begin{array}{lll}\begin{array}{l}\text { Future } \\
(\text { OECD })\end{array} & \text { of } & \text { Wo }\end{array}$ & $\begin{array}{l}\text { Technical and professional } \\
\text { skills (specific and sectoral } \\
\text { skills, such as the installation } \\
\text { and operation of robots) } \\
\text { General ICT skills (skills } \\
\text { needed to understand, use and } \\
\text { deploy technology; ability to } \\
\text { adapt to technological change) } \\
\text { Additional communication } \\
\text { skills in ICT (creative, } \\
\text { communication skills, critical } \\
\text { and logical thinking, } \\
\text { teamwork, digital } \\
\text { entrepreneurship) }\end{array}$ \\
\hline
\end{tabular}

Source: $[4,7,14]$

Human capital intellectualization accompanies the entire manufacturing process of modern enterprises, increasing its efficiency and simplifying economic security management at all levels. The key role is played by issues related to theoretical and practical principles of implementation of innovative processes in production, which are accompanied by the need to develop new approaches to the process of realizing the potential of economic security of enterprises.

The basic approaches to the economic security potential management mechanism of enterprises are determined by the goals of its development, the following basic approaches should be separated: systemic, process, resource, strategic, target, synergistic, functional and integrated. The potential economic security of the enterprise is a systemic formation that can be considered as the interdependence of such subsystems, which are the financial, production and personnel component in a set of relations and relationships between them, which affects its emergence. The potential of economic security includes a set of elements that determine to counteract the negative influence of the external and 
internal environment, forms its structure and is largely determined by political stability in society, the level of legal and information protection of society.

The process approach to the economic security potential management mechanism of enterprises involves characterizing the process of managing it, based on its understanding as a continuous process of managing an enterprise, which is in a certain external environment and prone to internal changes, stability of its functioning and creating opportunities for further development. From the point of view of the process approach, the assessment of the economic security potential is reduced to the analysis of existing processes, which are determined by the financial, production and personnel component and affect their status.

Within the resource approach, contractors' attention is focused on identifying and assessing the availability and use of available resources, capabilities and capabilities of enterprise staff. The selection of this approach corresponds to the current state of the enterprise, which operates in a highly competitive market environment: resources and their use are the main determinants of effective activity, the main factor for profit. The analysis of the impact of the environment on the potential of economic security of the enterprise is due to the fact that in the conditions of its high uncertainty, only the efforts of the enterprise itself, which has a set of resources and potential opportunities for their efficient use, provides a sustainable basis for its functioning.

The application of a strategic approach to managing the consistency between the goals of the enterprise, its potential for economic security, the requirements for competitive position in the market and the functioning of the enterprise in the long term in a changing external environment. A strategic approach as a management approach is appropriate, since managing the potential of economic security is a complex task with many variables, random factors and different constraints; errors in managerial decisions lead to bankruptcy. enterprise's potential of economic security of the mechanism of management is a system of methods, tools and methodical techniques that provide a permanent focus on managing the potential of economic security, decisions about the need for management, processes of implementation of these decisions aimed at managing the potential of economic security, taking into account available financial, human and production resources that identify the relevant components of the potential of economic security and to which the target is applied income.

The main task of the synergistic approach within the economic security potential management mechanism of the enterprise is not only its actual state, but also the consideration of the situation of choosing the process of managing it, which involves the connection between the object and the subject of management through the development of synergistic interaction of the elements of the mechanism, which aimed at self-organization and ensure management of the potential of economic security by taking into account available financial, human and production resources, environmental impact on performance functioning of the enterprise. Also, the structure of the production potential of economic security of enterprises is to ensure

The targeted approach within the framework of the

component is affected by the monetary valuation of fixed assets required to account for their dynamics, to plan extended reproduction, to establish depreciation and calculate depreciation, to determine the cost of production and profitability of the enterprise, and to carry out economic calculation. Accounting and planning of fixed assets are carried out not only in monetary terms, but also in natural terms in the form of specific means of labor. This is necessary in order to determine the technical composition, production capacity of enterprises and industries, to set tasks and ways of efficient use of production capacity to balance the equipment, etc [6].

Studying the factors that generate external and internal threats, it is necessary to distinguish external and internal functional components that affect the potential of economic security of the enterprise as a holistic system. External functional components of the effect are political-and-institutional, economic, social-anddemographic, scientific and technological environment, which both positively and negatively can affect the potential of economic security of the enterprise. Internal functional components of the impact on the potential of economic security of the enterprise are financial, production and personnel component, which perform the respective functions and influence each other. The separation of functional components allows identifying in a timely manner the emerging threats, the possible negative consequences of their impact and to competently and effectively minimize them or completely avoid them.

The enterprise's strategy of economic security potential management is based on the development of a long-term plan for the enterprise development, the implementation of a set of measures and specific actions by which highly effective results and economic security indicators are achieved. The strategic goal of managing the potential of economic security of the enterprise is a comprehensive counteraction to potential and real threats, the elimination or minimization of which should guarantee the enterprise the success of functioning and development in the conditions of instability of external and internal environment by using the potential of economic security. The economic security potential management strategy is the most important element of the economic security potential management mechanism of enterprises, as it identifies objects, indicators, indicators, dangers and threats, the main measures for their prevention or elimination, taking into account the real constraints of financial, human resources and production resources. According to Prokhorova V.V. and Yatsenko B.I. implementation of stages for the development of a strategy to ensure the development of innovative management of the competitive status of enterprises, as well as refining and adjusting it, obtaining information about the present and making forecasts for the future are carried out by using special methods of the overall strategy, i.e. ways to achieve its goals and objectives [8].

Despite the unconditional importance and priority of ensuring the realization of the economic security potential of

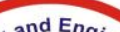
and Engin IJRTE 
enterprises, the lack of proper investment in human resources development in the digital economy will inevitably lead to a decrease in the efficiency of functioning of virtually all the components of the intellectual capital that directly related to all the approaches described above.

In the context of the concept of digitalisation of the economy, the stability of the functioning of enterprises and the economy of the state as a whole depends on the ability to create, use and increase innovative human capital, the fundamental components of which are information and knowledge, which in the conditions of the digital economy become the main means and subjects of social production.

The most obvious problems in this area for our country can be traced using the information on the Global Innovation Index. Ukraine's relative weaknesses are mainly accrued in innovation inputs, across all 5 GII input areas but mostly in Institutions. Institutions (107th), the lowest-ranked GII area for Ukraine, is itself signaled as a GII weakness. Here the country shows relatively weak performance in one of its three components, Political environment (122nd), as well as in the indicators Political stability \& safety (123rd), Rule of law (107th), and Ease of resolving insolvency (118th). In Human Capital \& Research (43rd), one relative weakness lies in the indicator Global R\&D companies expenditure (40th). In Infrastructure (89th), the area Ecological sustainability (115th) and the indicator GDP per unit of energy use (113th) present relatively weak performance. In Market Sophistication (89th), Ukraine exhibits relative weaknesses in one of its three components, Investment (115th), and in two indicators: Microfinance gross loans (79th) and Venture capital deals (79th). In Business Sophistication (46th), one GII weakness is found in the indicator State of cluster development (98st). On the innovation output side, only two indicators are signaled as weak: ICTs \& business model creation (106th) and National feature films (101st), both in Creative Outputs (45th) [3].

Therefore, the result of the information revolution and the transition to the digital economy should be an increase in the number of intellectual workers. The process of intellectualization of spheres of human activities and its direct influence on improving economic security is shown on Fig. 4.

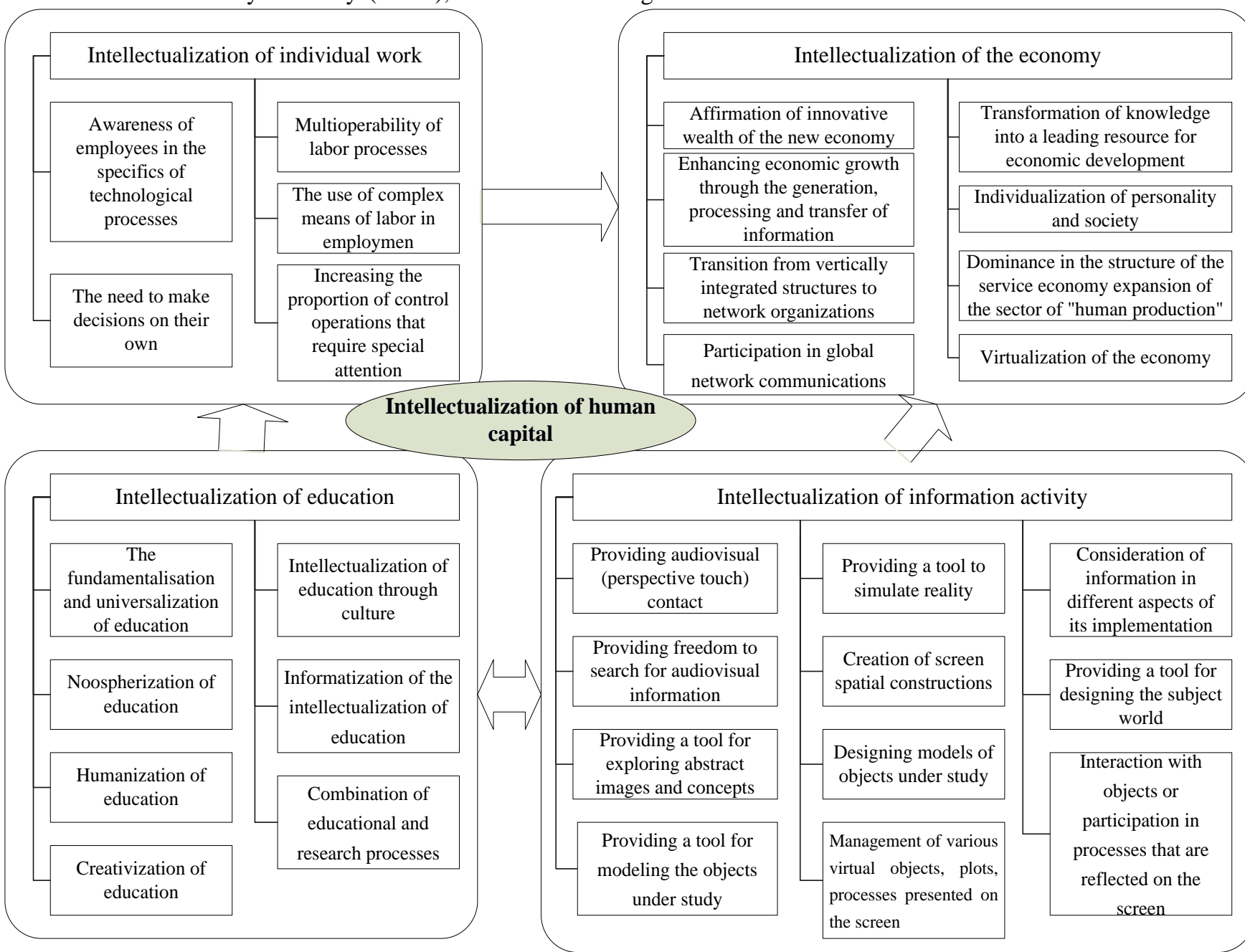

Fig. 4. The interconnection of the process of intellectualization of human capital and economic security of enterprises

Source: systematized by the authors on the basis of $[5,12,13]$ in the digital economy 
In terms of innovation and digital transformation of modern economic activity, the concept of "intelligent organization", which is revealed in the works of mostly foreign scientists, comes to the fore $[1,9,11]$. The main features of an "intellectual organization" are:

- the perception of chaos (edge of chaos) and uncertainty as its strategy;

- adaptation to changing situations and market conditions by balancing on the verge of stability (planning) and chaos, immediate response to unexpected market events due to the size of the system and the number of variations within the system;

- activity according to a model of parallel perception of the past, present and future, the transition from intentional chaos to spontaneous order, and from it to intentional chaos with the further reproduction of the cycle;

- the reverse orientation of thinking, that is, from the definite future to the present, the introduction of the future into the present;

- responsibility for their work and the right to make a mistake, since it is intended to participate in creative adaptation to an uncertain future;

- enhancing the creativity and innovation of each member of the organization;

- mutual trust, respect, honesty, loyalty and personal integrity;

- creation of creative environment;

- constant updating of the model, which combines individual creative input, teamwork, result, its correction and control with further reproduction of the cycle on a new basis.

The intellectual organization, according to supporters of this concept, is characterized by the ability to adapt, that is, spontaneous adaptation to change. This provokes the need for continuous management innovation, the search for new and improvement of existing systems and models of management, which characterize this type of organizations.

\section{CONCLUSION}

Significant systemic changes necessitate the justification of a new paradigm of economic growth in the absence of economic stability, dynamism and uncertainty, which give rise to the need for a new synthesis of fundamental theoretical and methodological structures that reveal the topic of growth boundaries in the substitution of knowledge. The quality of economic growth is viewed through the prism of the interconnection of changes in the technological basis of social production and social structure. The intellectual economy is interpreted, firstly, as a radical reform of the system of social relations and, secondly, as an essential criterion for the changes that take place and determine the results of the functioning of national and world economies. In our opinion, the new socio-economic relations, which envisage profound structural changes in the economic system, transformation of economic behavior and the resource base, determine the current quality of economic growth and the level of economic security in the digital economy.

\section{REFERENCES}

1. Chun Wei Choo (1998) Information management for the intelligent organization, Second edition, Medford, NJ: Information Today, Inc.

2. Global Competitiveness Index 2017-2018 of Ukraine, Available

at: http://reports.weforum.org/global-competitiveness-index2017-2018/countryeconomy-profiles/\#economy=UKR (Accessed: 30/10/2019)

3. Global Innovation Index, Available at: https://www.wipo.int/publications/en/details.jsp?id=4330 (Accessed: 30/10/2019)

4. ILO-ITU (2018) Digital Skills for Decent Jobs for Youth Campaign to train 5 million youth with job-ready digital skills

5. Kolot A.M., Gherasymenko O.O. Innovacijna pracja ta jiji intelektualizacija jak stratehični vektory stanovlennja novoji ekonomiky [Ensuring innovative management of the competitive status of machine-building enterprises: organizational and economic aspect]. Economics and organization of management, 1(29), pp. 6-23 (in Ukrainian) (2018)

6. Mykhailenko V. M., Arefiev S. O. Formuvannia orhanizatsiinoho potentsialu rozvytku ekonomichnoi bezpeky pidpryiemstv: monohrafiia [Formation of organizational potential for development of economic security of enterprises: monograph]. Lviv: Ukr. Acad. Printing. (in Ukrainian) (2010)

7. OECD (2016) Skills for a digital world, Policy Brief on the Future of Work

8. Prokhorova V.V., Yatsenko B. I. Zabezpechennia innovatsiinoho upravlinnia konkurentnym statusom mashynobudivnykh pidpryiemstv: orhanizatsiino-ekonomichnyi aspect [Ensuring innovative management of the competitive status of machine-building enterprises: organizational and economic aspect]. Business Inform, no. 11, pp. 386-391(in Ukrainian) (2016)

9. Rubynshtejn M., Fyrstenbergh A. (2003) Intellektualjnaja orghanyzacyja [Intellectual organization]. Moscow: INFRA-M (in Russian)

10. State Statistics Service of Ukraine, Available at: http://www.ukrstat.gov.ua/ (Accessed: 30/10/2019)

11. Stein R. G., Pinchot G. (1995) Building an Intelligent Organization. Association Management

12. Subetto A.Y. Intellektualyzacyja obrazovanyja kak problema XXI veka [Intellectualization of education as a problem of the 21st century] (in Russian), Available at: http://www.trinitas.ru/rus/ doc/0012/001a/00120061.htm (Accessed: 30/10/2019)

13. Blyznyu T., Lepeyko T. Profile of modern Ukrainian manager. Proceedings Cross-Cultural Business Conference, pp 256-266 (2016)

14. World Economic Forum (2016) The Future of Jobs: Employment, Skills and Workforce Strategy for the Fourth Industrial Revolution, Geneva. 


\section{AUTHORS PROFILE}

Olena Arefieva - Professor, Doctor of Economic Sciences, is the Head of the Department of Air Transport Economics at National Aviation University. Has trained $37 \mathrm{PhD}$ (Economics) and 5 Doctors of Economic sciences. Olena Arefieva is head of R\&D "Management of Sustainable Development of integration processes of Air Transport Enterprises in the international space".

Consequently the sphere of scientific interests of Professor Arefieva O. is associated with management and organization of functioning of large integrated industrial-financial systems, economic problems of the theory and practice of management of sustainable development of economic systems; scientific bases of adaptation of entrepreneurship in the conditions of transformation of economy; strategic management of aviation enterprises and formation of economic security.

The results of the scientific work include over 235 scientific and methodological works, including 143 scientific papers, 28 educational and methodical works and 23 collective monographs.

ORCID ID 0000-0001-5157-9970

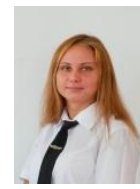

Olga Polous - PhD (Economics), Associate Professor of the Department of Air Transport Economics, National Aviation University. Scientific interests concern all manifestations of human capital development at different levels, the process of intellectualization of labor in the knowledge economy, innovation activity of aviation sector enterprises in the era of global economic transformations.

She has published more than 72 scientific and methodological works, including 1 guidelines, 1 workshop, 27 scientific papers and 4 collective monographs.

Polous O. teaches the subjects "Business Economics", "Forecasting and macroeconomic planning", "Technology transfer in economics", and others. Supervises the implementation of qualification work by students of the department. Participates in the preparation of student research projects and conferences.

ORCID ID 0000-0002-4639-4493

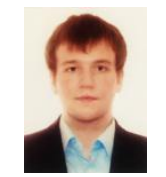

Volodymyr Arefiev - PhD (Economics), economist Prima Leader Group. He has published more than 30 scientific works. Arefiev V. is engaged in research of scientific and theoretical approaches to managing the formation of financial security of enterprises. Analyzes the state and substantiates the tendencies of development of heavy machine-building, estimation of current and strategic component of financial security of the enterprises of railway transport machine-building as the stipulated factor of ensuring the financial security of their activity. Develops a methodological approach to the integrated assessment of the financial security level of railway transport engineering enterprises and its management mechanism. He proposed the conceptual framework for managing the financial security of railway transport engineering enterprises at strategic and tactical levels. Developed measures to ensure the necessary level of financial security for the enterprises of railway transport machine building on the basis of forecasting its integral index.

ORCID ID 0000-0003-3815-9917

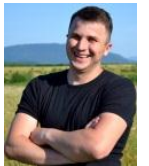

Yuri Kopcha - postgraduate of the the Department of Air Transport Economics, National Aviation University. He has published more than 7 scientific works. The researches are devoted to deepening of theoretical approaches and development of recommendations on formation of strategic guidelines for managing the potential of economic security of enterprises. The attention is paid to machine-building enterprises which, due to the large number of dangers, largely caused by the specifics of national market relations, have to act in situations of high risk, so it is necessary to envisage such measures to ensure the economic security of the enterprise, which could minimize the adverse effects and negative impact of internal and external threats. He is engaged in the development of strategic guidelines that would ensure a balanced pace of permanent growth and safe development of the enterprise, taking into account its protection against internal and external threats for a long enough period.

ORCID ID 0000-0001-6639-6421 